\title{
Assessing the Response of Tomato Yield, Fruit Composition, Nitrogen Absorption, and Soil Nitrogen Fractions to Different Fertilization Management Strategies in the Greenhouse
}

\author{
Pengpeng Duan \\ Key Laboratory of Northeast Arable Land Conservation, Ministry of Agriculture, \\ College of Land and Environment, Shenyang Agricultural University, Shenyang \\ 110866, China; and Jiangsu Key Laboratory of Low Carbon Agriculture and \\ GHGs Mitigation, College of Resources and Environmental Sciences, Nanjing \\ Agricultural University, Nanjing 210095, China
}

\section{Ying Sun, Yuling Zhang', Qingfeng Fan, Na Yu, Xiuli Dang, and Hongtao Zou}

Key Laboratory of Northeast Arable Land Conservation, Ministry of Agriculture, College of Land and Environment, Shenyang Agricultural University, Shenyang 110866, China

Additional index words. greenhouse, tomato yield, tomato composition, nitrogen absorption, soil nitrogen fraction, fertilization management

\begin{abstract}
A greenhouse field experiment involving tomato (Solanum lycopersicum) was performed using different nitrogen $(\mathrm{N})$ management regimes: sole application of differing rates of chemical $\mathbf{N}$ fertilizer (SC) (SC treatments: N0, N1, N2, and N3) and combined application of manure and chemical N fertilizer (MC) (MC treatments: MNO, MN1, MN2, and MN3). These were used to understand the relationship between comprehensive fruit composition, yield, and $\mathbf{N}$ fractions (soil mineral $\mathbf{N}$; soil soluble organic $N$; soil microbial biomass $N$, and soil fixed ammonium) under greenhouse conditions. The results showed that the MC treatments significantly increased vitamin $\mathrm{C}$ and soluble sugar content compared with SC treatments. In addition, the MN2 treatment produced a high yield and had a positive effect on fruit composition. The $N 3(563 \mathrm{~kg} \mathrm{~N} / \mathrm{ha})$ and MN3 (796 kg N/ha) treatments resulted in a high loss of $N$ below the root zone (0-30 $\mathrm{cm}$ ), consequently reducing $\mathbf{N}$ use efficiency. Soil mineral $\mathrm{N}$, soil soluble organic $\mathrm{N}$, and soil fixed ammonium tended to be higher during the first fruiting period, whereas soil microbial biomass $\mathrm{N}$ tended to be higher during the second fruiting period. MC treatments significantly increased the $\mathrm{N}$ fraction in the 0 - to $30-\mathrm{cm}$ soil layer; $\mathrm{N}$ fractions tended to be higher with the MN2 treatment. According to an optimum regression equation, soil fixed ammonium during the first fruiting period and soil microbial biomass $\mathrm{N}$ during the second fruiting period had a more significant influence on tomato yield and fruit composition. Overall, application $\mathrm{MC}$ at an appropriate rate (MN2: $608 \mathrm{~kg} \mathrm{~N} / \mathrm{ha})$ is a promising approach to achieving high yields and optimum taste, and it offers a more sustainable fertilizer management strategy compared with chemical $\mathbf{N}$ fertilization.
\end{abstract}

Changes in the soil total nitrogen $(\mathrm{N})$ pool occur slowly in response to changing management practices. Due to its large size and

Received for publication 14 Sept. 2018. Accepted for publication 15 Jan. 2019.

This research was supported by National Key Technology Research and Development Program of the Ministry of Science and Technology of China (grant number 2015BAD23B01). It was also financially supported by the National Natural Science Foundation of China (grant number 41401322). We thank Editage for English language editing.

${ }^{1}$ Corresponding author. E-mail: yuling_zhang@ 163.com. et al., 2010; Jones et al., 2005). However, the soil mineral $\mathrm{N}$ content in soil is highly variable due to $\mathrm{NO}_{3}{ }^{-} \mathrm{N}$ leaching and $\mathrm{NH}_{4}{ }^{+}-\mathrm{N}$ loss through volatilization (Liu et al., 2016). Soil soluble organic $\mathrm{N}$ plays an important role in ecological processes, including $\mathrm{N}$ leaching, mineralization, and uptake by crop plants and microorganisms, and it is an indicator of changes in soil and fertilizer management (Sharifi et al., 2007). Numerous studies have shown that plants can directly take-up inorganic $\mathrm{N}$ as well as some small organic $\mathrm{N}$ compounds (e.g., amino acids and peptides) (Ge et al., 2009; Li et al., 2013; Paungfoo-Lonhienne et al., 2008; Soper et al., 2011). Gouveia and Eudoxie (2007) postulated that soil fixed ammonium might act in a manner similar to that of a slowrelease $\mathrm{N}$ source, thus improving soil $\mathrm{N}$ management. Ammonium fixation and release are important in the $\mathrm{N}$ cycle, and both prevent $\mathrm{N}$ loss and improve fertilizer $\mathrm{N}$ use efficiency (Nieder et al., 2011). Soil microbial biomass $\mathrm{N}$ is the most labile form of soil organic $\mathrm{N}$ because of the rapid generation of soil microbial biomass, and it is an indicator of the degree of soil fertility and the quality of agricultural management (Ge et al., 2012). Because the average life cycle of $\mathrm{N}$ in microbial biomass is only a matter of days, it is speculated that much immobilized $\mathrm{N}$ is rapidly transformed to microbial residues (Kuzyakov and Xu, 2013). Conservation fertilization management, such as a single application of chemical fertilizer or organic manure, may temporarily reduce available $\mathrm{N}$ in plants by increasing $\mathrm{N}$ immobilization, or it may increase the risk of excessive loss of $\mathrm{N}$ to the environment. However, coapplication of $\mathrm{N}$ fertilizer with organic manure can improve $\mathrm{N}$ availability in crops during the long term by improving soil $\mathrm{N}$ retention and increasing the labile $\mathrm{N}$ pool in the upper soil layers (Masaka et al., 2013; Stålnacke et al., 2014).

Tomato (Solanum lycopersicum) is a globally important and widely consumed vegetable crop that provides a rich source of minerals, vitamin $\mathrm{C}$, organic acids, essential amino acids, and antioxidants (Erba et al., 2013). Its consumption has been suggested to be beneficial for lowering the risk of contracting some diseases in humans (Al-Amri, 2013). Recently, large areas of China traditionally used for cereal cultivation have been transferred to intensive greenhouse cultivation due to rapid economic development in this agricultural sector and increased consumer demand (Quan et al., 2015). However, the rapid growth rates and poorly developed root systems found in greenhousegrown tomato plants require relatively high levels of water and a high nutrient supply (Willekens et al., 2014). Furthermore, production is highly dependent on $\mathrm{N}$ fertilizers and organic manure, which maintain crop yield despite declining natural soil fertility. Inputs of $\mathrm{N}$ often exceed crop requirements to maximize yields; however, this can lead to $\mathrm{NO}_{3}{ }^{-}$leaching and affect the nitrate content in tomato fruits (Kuscu et al., 2014; Wang et al., 2012), thereby changing the soil $\mathrm{N}$ 
transformation process. Additionally, manure incorporated in soil in excess of crop requirements may contribute to the pollution of groundwater by nitrates (Kirchmann and Bergström, 2001; Vogeler et al., 2007). Therefore, it is reasonable to presume that an optimal fertilizer management strategy would balance the improvement of soil fertility and result in obtaining relatively high crop yields and fruit composition.

The response of tomato yield and fruit composition to manure and inorganic $\mathrm{N}$ fertilizer has been the subject of several studies, but results have focused on the effects of inorganic $\mathrm{N}$ fertilizer on $\mathrm{N}$ fractions in open fields. A few studies have addressed dynamic variation in soil mineral $\mathrm{N}$, soil soluble organic $\mathrm{N}$, soil microbial biomass $\mathrm{N}$, and soil fixed ammonium in greenhouse soil. Therefore, the present study aimed to explore 1) the different fertilization strategies for tomato yield and comprehensive fruit composition under greenhouse conditions; 2) the mechanisms underlying the variations in soil mineral $\mathrm{N}$, soil soluble organic $\mathrm{N}$, soil microbial biomass $\mathrm{N}$, and soil fixed ammonium in three different layers of soil under different fertilization strategies; and 3) the relationship between tomato yield, fruit composition, and $\mathrm{N}$ fractions under greenhouse conditions.

\section{Materials and Methods}

Site description. The experimental site (lat. $41^{\circ} 49^{\prime} \mathrm{N}$, long. $123^{\circ} 34^{\prime} \mathrm{E}$ ) is located in a greenhouse vegetable field $(4 \mathrm{~m} \times 6 \mathrm{~m} \times$ $80 \mathrm{~m}$ ) covered with polyethylene film that was established in 2012 at Shenyang Agricultural University in China. The region has a continental monsoon climate, with a mean annual precipitation of $730 \mathrm{~mm}$, and a mean annual temperature of 7.0 to $8.1{ }^{\circ} \mathrm{C}$. To improve soil fertility, cow manure (22.5 t.ha ${ }^{-1}$, fresh weight) and chicken manure (37.5 t.ha $\mathrm{h}^{-1}$, fresh weight) were applied to cultivated land in the greenhouse during Spring 2012 and Spring 2013. The experiment was conducted during the monoculture tomato cultivation period (April to August) and during the fallow period. The median temperatures in the greenhouse were $23{ }^{\circ} \mathrm{C}$ (May), $28{ }^{\circ} \mathrm{C}$ (June), $31{ }^{\circ} \mathrm{C}$ (July), $30{ }^{\circ} \mathrm{C}$ (August), and $23{ }^{\circ} \mathrm{C}$ (September) in 2014. The soil was classified as Hapli-Udic Cambisol (FAO Classification). Tomato was planted starting in 2013. Table 1 summarizes the main chemical and physical properties of the soil before land preparation in 2012 .

Experimental design. The experiment followed a randomized block design and con- sisted of 24 plots $(2.5 \mathrm{~m} \times 1.5 \mathrm{~m})$. Three replicates of each of the sole applications of chemical fertilizer (SC) [0 kg N/ha (N0); 188 $\mathrm{kg} \mathrm{N} / \mathrm{ha}(\mathrm{N} 1) ; 375 \mathrm{~kg} \mathrm{~N} / \mathrm{ha}(\mathrm{N} 2) ; 563 \mathrm{~kg} \mathrm{~N} / \mathrm{ha}$ (N3)] and combined applications of manure with chemical $\mathrm{N}$ fertilizer (MC) $[7.5 \mathrm{t}$ manure/ha, $0 \mathrm{~kg} \mathrm{~N} / \mathrm{ha}(\mathrm{MN} 0,233 \mathrm{~kg} \mathrm{~N} / \mathrm{ha})$; $7.5 \mathrm{t}$ manure $/ \mathrm{ha}, 188 \mathrm{~kg} \mathrm{~N} / \mathrm{ha}(\mathrm{MN} 1,421 \mathrm{~kg}$ $\mathrm{N} / \mathrm{ha}$ ); $7.5 \mathrm{t}$ manure/ha, $375 \mathrm{~kg} \mathrm{~N} / \mathrm{ha}(\mathrm{MN} 2$, $608 \mathrm{~kg} \mathrm{~N} / \mathrm{ha}) ; 7.5 \mathrm{t}$ manure $/ \mathrm{ha}, 563 \mathrm{~kg} \mathrm{~N} / \mathrm{ha}$ (MN3, $796 \mathrm{~kg} \mathrm{~N} / \mathrm{ha})]$ were used. Treatments were separated from each other using polyethylene film $(60 \mathrm{~cm})$. A commercial chicken manure containing $21.7 \mathrm{~g} \cdot \mathrm{kg}^{-1}$ organic carbon, $3.1 \mathrm{~g} \cdot \mathrm{kg}^{-1}$ total $\mathrm{N}, 5.67 \mathrm{mg} \mathrm{N} / \mathrm{kg} \mathrm{NH}_{4}{ }^{+}$ $\mathrm{N}$, and $3.25 \mathrm{mg} \mathrm{N} / \mathrm{kg} \mathrm{NO}_{3}{ }^{-}-\mathrm{N}$ (dry weight) was used. The manure was incorporated into the soil layer of $0-20 \mathrm{~cm}$ at a rate of $7.5 \mathrm{t} \cdot \mathrm{ha}^{-1}$ before planting (29 Apr. 2014). Urea (46\% N) was used as the main chemical $\mathrm{N}$ fertilizer.

During each season, all plots received 225 $\mathrm{kg}_{2} \mathrm{O}_{5} /$ ha as calcium monophosphate $(12 \%$ $\mathrm{P}_{2} \mathrm{O}_{5}$ ) and $450 \mathrm{~kg} \mathrm{~K} \mathrm{~K}_{2} \mathrm{O} / \mathrm{ha}$ as potassium sulfate $\left(50 \% \quad \mathrm{~K}_{2} \mathrm{O}\right)$. Manure, $\mathrm{P}$ fertilizer, one-third $\mathrm{N}$ fertilizer, and one-third $\mathrm{K}$ fertilizer were used as the base fertilizer; twothirds $\mathrm{N}$ fertilizer and two-thirds $\mathrm{K}$ fertilizer were used as dressing during the growth periods when the first and second fruit trusses were setting with the trickle irrigation method. Trickle irrigation was commenced when tomatoes were first planted (29 Apr. 2014). Irrigation was restarted every 3-5 days, and it was stopped after harvesting (19 July 2014). Using a tensiometer as an irrigation indicator, the lower control limit was determined to be $-35 \mathrm{kPa}$. The rate of irrigation for each treatment was $100 \mathrm{~m}^{3} \cdot \mathrm{ha}^{-1}$ throughout the tomato growth period. Other management practices, including the choice of crop species, tillage, and pesticide and weed control, were conducted according to the local practices of the farmer. Management practices were the same every year.

Crop management. Tomato plants were transplanted on 29 Apr. 2014. Twenty-four tomato seedlings were evenly transplanted along each edge of the raised bed. Each furrow was $0.35 \mathrm{~m}$ wide and $0.20 \mathrm{~m}$ deep. The soil surface was covered by polyethylene film. Furrow fertigation was conducted beneath the film. Nylon cord guides were used to support the tomato plants vertically. Other agronomic measures, such as pollination, pruning, pest control, and potassium and phosphorous fertilization, were the same for all treatments and were in accordance with local practices. All plots were planted with the same crop types and using the same crop rotation pattern. After tomatoes were harvested, the produce was weighed; the sum of the weights of the fruits planted from the first day to the last day of the year was considered the annual crop yield.

Soil and plant sampling and analysis. Three soil cores $(3.5 \mathrm{~cm}$ in diameter) were taken from each plot to a depth of $30 \mathrm{~cm}$ and subdivided into depth increments of $0-10$, 10-20, and $20-30 \mathrm{~cm}$ before the application of the first and second top dressings (on 31 May 2014, first fruiting period; on 28 June 2014 , second fruiting period) and at the end of the growth period (on 26 July 2014, harvest period). Fresh soil cores were mixed thoroughly to provide a composite sample from each plot. The soil samples were divided into two groups. One group was stored at $4{ }^{\circ} \mathrm{C}$, and the other was air-dried. The first group of the soil sample was air-dried to estimate soil fixed ammonium; the other was passed through a 2-mm mesh screen before being immediately transferred to the laboratory for soil mineral $\mathrm{N}$, soil soluble organic $\mathrm{N}$, and soil microbial biomass $\mathrm{N}$ analysis.

Field-moist soil equivalent to $5.0 \mathrm{~g}$ dry soil was shaken with $50 \mathrm{~mL}$ of $1 \mathrm{M} \mathrm{CaCl}_{2}$ on a reciprocating shaker for $30 \mathrm{~min}$; then, it was filtered through a filter membrane $(<0.45 \mu \mathrm{m}) . \mathrm{NO}_{3}{ }^{-}-\mathrm{N}$ and $\mathrm{NH}_{4}{ }^{+}-\mathrm{N}$ contents in the leachates were measured using a continuous flow analyzer (AutoAnalyzer 3; Bran+Luebbe, Norderstedt, Germany). Soil mineral $\mathrm{N}$ content was calculated as the sum of $\mathrm{NO}_{3}{ }^{-}-\mathrm{N}$ and $\mathrm{NH}_{4}{ }^{+}-\mathrm{N}$. First, soil total soluble $\mathrm{N}$ in the leachates was oxidized using alkaline potassium persulfate solution $\left(0.15 \mathrm{M} \mathrm{NaOH}\right.$ and $\left.3 \% \mathrm{~K}_{2} \mathrm{~S}_{2} \mathrm{O}_{8}\right)$ at $123{ }^{\circ} \mathrm{C}$ for $30 \mathrm{~min}$; then, it was measured using the AutoAnalyzer 3 . The soil soluble organic N content was calculated as the difference between the soil total soluble $\mathrm{N}$ and soil mineral $\mathrm{N}$ content.

Soil fixed ammonium was determined using the $\mathrm{KOBr}-\mathrm{KOH}$ method (Bremner and Keeney, 1966). Briefly, $2 \mathrm{~g}$ of dry soil was placed in a tall-form beaker and treated with alkaline potassium hypobromite $(\mathrm{KOBr}-\mathrm{KOH})$ solution to remove exchangeable $\mathrm{NH}_{4}{ }^{+}$and soil organic $\mathrm{N}$. The clear supernatant liquid was decanted and discarded, and the residue was transferred to a polyethylene centrifuge tube with $0.5 \mathrm{M} \mathrm{KCl}$ and washed three times with $0.5 \mathrm{M} \mathrm{KCl}$ to remove residual exchangeable $\mathrm{NH}_{4}{ }^{+}$. After decanting the clear supernatant liquid, the residue was treated with $5 \mathrm{~N} \mathrm{HF}+1 \mathrm{~N} \mathrm{HCl}$ solution and placed in a rotary shaker for $24 \mathrm{~h}$ to disintegrate the clay minerals containing fixed $\mathrm{NH}_{4}{ }^{+}$. The $\mathrm{NH}_{4}{ }^{+}$released by $\mathrm{HF}-\mathrm{HCl}$ was determined by steam distillation of the soil-acid mixture with $10 \mathrm{M} \mathrm{KOH}$ and quantified by titration.

Table 1. The physical-chemical properties of soil before the trial in 2012 .

\begin{tabular}{|c|c|c|c|c|c|c|c|c|c|}
\hline $\begin{array}{l}\text { Soil layer } \\
(\mathrm{cm})\end{array}$ & $\begin{array}{c}\text { Organic } \\
\text { matter }\left(\mathrm{g} \cdot \mathrm{kg}^{-1}\right)\end{array}$ & $\begin{array}{l}\text { Total N } \\
(\mathrm{g} \mathrm{N} / \mathrm{kg})\end{array}$ & $\begin{array}{c}\text { Avail. P } \\
(\mathrm{mg} \mathrm{P} / \mathrm{kg})\end{array}$ & $\begin{array}{c}\text { Avail. K } \\
(\mathrm{mg} \mathrm{K} / \mathrm{kg})\end{array}$ & $\mathrm{pH}\left(\mathrm{H}_{2} \mathrm{O}\right)$ & $\begin{array}{c}\text { Soil bulk } \\
\text { density }\left(\mathrm{g} \cdot \mathrm{cm}^{-3}\right)\end{array}$ & Sand (\%) & Silt (\%) & Clay $(\%)$ \\
\hline $0-10$ & 25.19 & 2.14 & 13.49 & 29.67 & 7.12 & 1.02 & 33.1 & 43.3 & 23.6 \\
\hline $10-20$ & 8.38 & 1.24 & 11.26 & 42.52 & 7.01 & 1.16 & 31.5 & 45.8 & 22.7 \\
\hline $20-40$ & 9.83 & 1.45 & 8.45 & 35.48 & 6.98 & 1.29 & 25.5 & 47.4 & 27.1 \\
\hline $40-60$ & 11.96 & 1.45 & 9.23 & 63.32 & 7.04 & 1.37 & 27.6 & 45.5 & 26.9 \\
\hline
\end{tabular}


Soil microbial biomass $\mathrm{N}$ was estimated using the chloroform fumigation extraction method (Brookes et al., 1985; Vance et al., 1987) with a purified $\mathrm{CHCl}_{3}$ treatment, followed by $0.5 \mathrm{M} \mathrm{K}_{2} \mathrm{SO}_{4}$ extraction of both fumigated and nonfumigated soils as total $\mathrm{N}$ using the Kjeldahl digestion procedure (Brookes et al., 1985). Microbial biomass N was estimated using the following equation: soil microbial biomass $\mathrm{N}=\mathrm{EN} / \mathrm{k}_{\mathrm{EN}}$, where $\mathrm{EN}$ is the difference between the quantity of $\mathrm{N}$ extracted from the $\mathrm{K}_{2} \mathrm{SO}_{4}$ extract of fumigated and nonfumigated soil (both expressed as $\mathrm{mg} \mathrm{N} / \mathrm{g}$ oven-dry soil) and $\mathrm{k}_{\mathrm{EN}}=0.54$ is the fraction of biomass $\mathrm{N}$ extracted after chloroform fumigation.

Above-ground samples (partitioned into stems and leaves) were collected from each plot during the harvest period. All plant samples were dried in the oven at $70{ }^{\circ} \mathrm{C}$ for more than $48 \mathrm{~h}$; samples were weighed before and after drying to determine water content. Six tomato fruits of similar size and maturity with no external defects were picked per plot to measure composition parameters. Tomato fruits were picked twice during the growth season, when the second and third fruit trusses were ripened (they had turned red). The average values of each plot were adopted as the fruit composition parameters. The fruits were then liquidized in a blender.

Organic acid was titrated with $0.1 \mathrm{~mol} \cdot \mathrm{L}^{-1}$ $\mathrm{NaOH}$ solution. Soluble sugar content was measured using the anthrone-sulfuric acid colorimetric method (Leyva et al., 2008) and calculated according to the following: soluble sugar $(\%)=\mathrm{C} \times \frac{\mathrm{V}}{a} \times \mathrm{n} \times 100 / W \times 1000 \times 1000$, where $\mathrm{C}$ is the amount of the glucose in the sample tube from the standard curve $(\mu \mathrm{g}), n$ is the dilution ratio, $\mathrm{V}$ is the volume of the sample after dilution $(\mathrm{mL}), a$ is the volume of sample extracted before determination $(\mathrm{mL})$, $W$ is the weight of the sample $(\mathrm{g})$, and 1000 is the conversion ratio derived from $1 \mathrm{mg}=$ $1000 \mu \mathrm{g}$.

Vitamin C content was measured using the 2,6-dichloroindophenol titrimetric method (Chen et al., 2013). Nitrate content was determined using the spectrophotometric method (García-Robledo et al., 2014) and calculated according to the following: nitrate $\left(\mathrm{mg} \cdot \mathrm{kg}^{-1}\right)=\frac{\mathrm{C} \times \mathrm{V}}{\mathrm{W}}$, where $C$ is the nitrate concentration calculated by the equation of regression $\left(\mathrm{mg} \cdot \mathrm{L}^{-1}\right), V$ is the volume extracted from the sample $(\mathrm{mL})$, and $W$ is the fresh weight of the sample $(\mathrm{g})$.
Total $\mathrm{N}$ values in the fruit, leaf, and stem parts were analyzed using the Kjeldahl method following digestion by $\mathrm{H}_{2} \mathrm{SO}_{4}-\mathrm{H}_{2}$ $\mathrm{O}_{2}$ (Thomas et al., 1967).

Statistical analysis. Results in the Tables and Figures are the means of three replicates expressed based on oven-dry weight. Data were analyzed by a repeated measures analysis of variance (ANOVA) to determine the effects of treatment, sampling time, and soil depth on soil mineral $\mathrm{N}$, soil soluble organic $\mathrm{N}$, soil fixed ammonium, and soil microbial biomass N. A randomized block one-way ANOVA was used to determine the significant differences between chemical and manure treatments by a least significant difference test at a level of $\alpha=0.05$ or 0.01 . The correlation $(P<0.05)$ among soil mineral $\mathrm{N}$, soil soluble organic $\mathrm{N}$, soil fixed ammonium, soil microbial biomass, tomato yield, and fruit composition were analyzed using Pearson's correlation coefficients. These were further tested using a multivariate regression analysis to determine the regression equation and $\mathrm{R}$ square coefficients. Because the variables analyzed in the present work were on different scales, they were preprocessed using a correlation analysis before calculating the equation models to give the same a priori importance
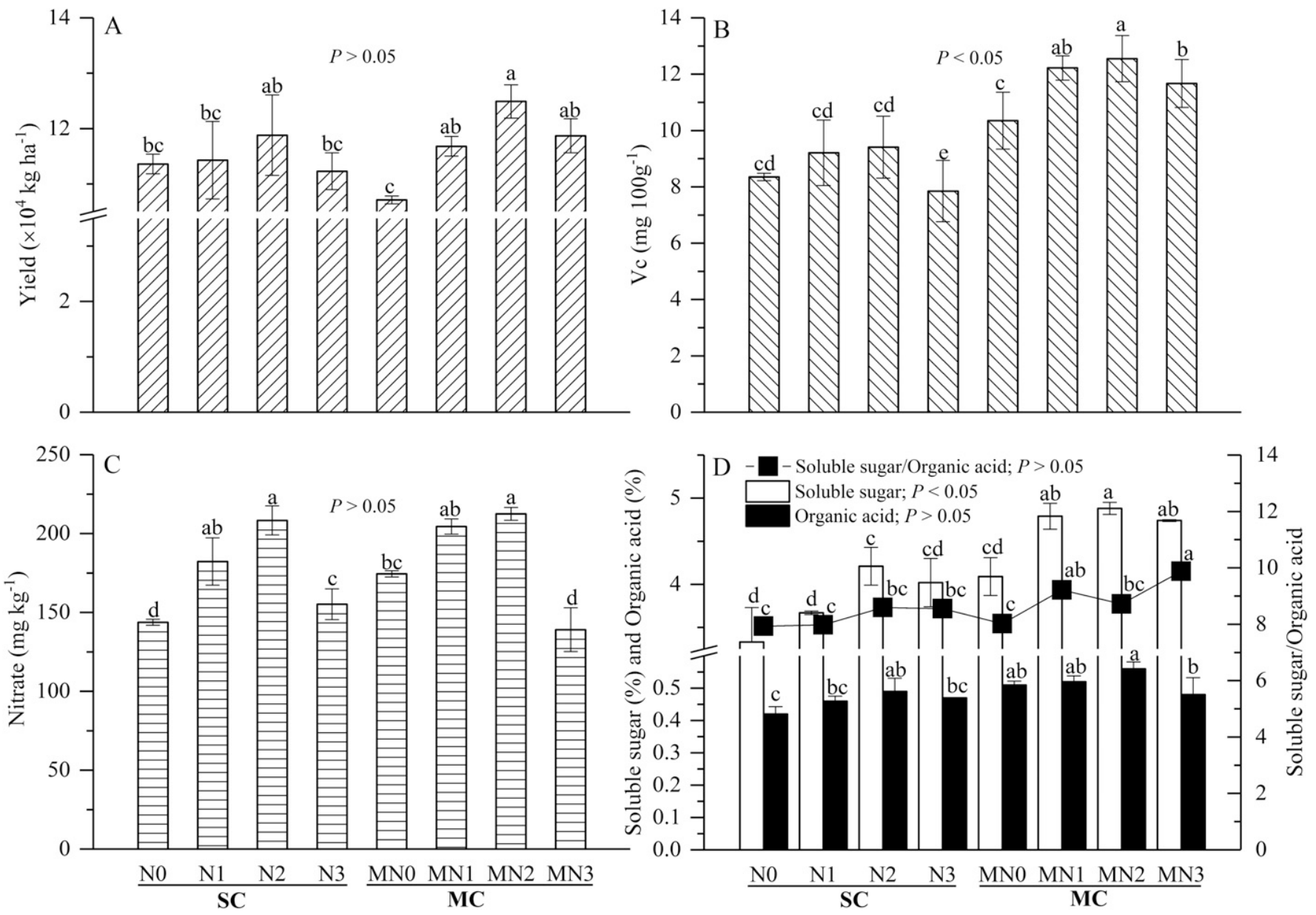

Fig. 1. The tomato yield and fruit composition with different fertilization management. The vertical bars represent standard errors. Values with different lowercase letters are significantly different at $P<0.05, P<0.05$, or $P>0.05$ indicated a significant or nonsignificant difference between SC and MC treatments, respectively. SC: sole application of chemical fertilizer: $0 \mathrm{~kg} \mathrm{~N} / \mathrm{ha}(\mathrm{N} 0) ; 188 \mathrm{~kg} \mathrm{~N} / \mathrm{ha}(\mathrm{N} 1) ; 375 \mathrm{~kg} \mathrm{~N} / \mathrm{ha}(\mathrm{N} 2)$; and $563 \mathrm{~kg} \mathrm{~N} / \mathrm{ha}$ (N3). MC: combined applications of manure with chemical N fertilizer: $233 \mathrm{~kg} \mathrm{~N} / \mathrm{ha}$ (MN0); $421 \mathrm{~kg} \mathrm{~N} / \mathrm{ha}(\mathrm{MN} 1) ; 608 \mathrm{~kg} \mathrm{~N} / \mathrm{ha}(\mathrm{MN} 2)$; and $796 \mathrm{~kg} \mathrm{~N} / \mathrm{ha}(\mathrm{MN} 3)$. 
to each of the original variables. A stepwise regression analysis was finally used to determine the optimum regression equation based on an $F$-test and $t$ test at $\alpha=0.05$, with a d value of the statistical variable closer to 2 . All statistical analyses were conducted using SPSS Windows version 19.0 (SPSS Inc., Chicago, IL).

\section{Results}

Tomato yield, fruit composition, and $N$ absorption. The tomato yield was significantly higher with the MN2 treatment (1.25 $\times 10^{5} \mathrm{~kg} \cdot \mathrm{ha}^{-1}$ ) than with the N0, N1, N3, and
MN0 treatments $(P<0.05)$; however, there were no significant differences observed between the $\mathrm{SC}$ and $\mathrm{MC}$ treatments $(P>$ 0.05) (Fig. 1A).

Compared with the SC treatments, MC treatments significantly increased $\mathrm{VC}$ and soluble sugar content $(P<0.05)$ (Fig. 1B and D). However, there was no significant difference in nitrate, organic acid, or soluble sugar/organic acid contents between the two types of treatments $(P>0.05)$ (Fig. 1C and D). In general, the response of $\mathrm{VC}$, soluble sugar, nitrate, and organic acid to the $\mathrm{N}$ rates were quadratic in form, peaking at MN2; however, soluble sugar/organic acid was lower with the MN2 treatment $(P<0.05)$ (Fig. 1). Nitrate content with the MN3 treatment was significantly lower than with the N3 treatment $(P<0.05)$.

The $\mathrm{N}$ absorption proportion (aboveground biomass $\mathrm{N}+$ accumulated tomato yield $\mathrm{N} / \mathrm{N}$ input) decreased from $32.4 \%$ to $13.3 \%$ as the rate of the application of chemical $\mathrm{N}$ fertilizer increased from $\mathrm{N} 1$ to $\mathrm{N} 3$ (Table 2). The $\mathrm{N}$ losses below the $30-\mathrm{cm}$ depth were 461 and $524 \mathrm{~kg} \mathrm{~N} /$ ha for the N3 and MN3 treatments, respectively (Table 2). $\mathrm{N}$ accumulation (soil total $\mathrm{N}$ ) varied highly

Table 2. Apparent $\mathrm{N}$ balance between $\mathrm{N}$ input and output together with $\mathrm{N}$ loss $(0-30 \mathrm{~cm}, \mathrm{~kg} \mathrm{~N} / 3$ years $)$ at the end of the 3 -year vegetable cultivation in a greenhouse.

\begin{tabular}{|c|c|c|c|c|c|c|c|}
\hline Treatment $^{z}$ & $\begin{array}{l}\mathrm{N} \text { input }{ }^{\mathrm{y}} \\
(\mathrm{kg} \mathrm{N} / \mathrm{ha})\end{array}$ & $\begin{array}{l}\text { Accumulated soil } \\
\mathrm{TN} \text { in } 0-30 \mathrm{~cm} \text { soil } \\
\text { layer }(\mathrm{kg} \mathrm{N} / \mathrm{ha})\end{array}$ & $\begin{array}{l}\mathrm{N} \text { absorption }{ }^{\mathrm{x}} \\
(\mathrm{kg} \mathrm{N} / \mathrm{ha})\end{array}$ & $\begin{array}{c}\mathrm{N} \text { loss }{ }^{\mathrm{w}} \\
(\mathrm{kg} \mathrm{N} / \mathrm{ha})\end{array}$ & $\begin{array}{l}\text { Accumulated soil } \\
\text { TN/N input }\end{array}$ & $\begin{array}{c}\mathrm{N} \text { absorption } / \mathrm{N} \\
\text { input }\end{array}$ & $\begin{array}{c}\mathrm{N} \text { loss } / \mathrm{N} \\
\text { input }\end{array}$ \\
\hline$\overline{\mathrm{N} 0}$ & 0 & $12 \pm 2.7 \mathrm{e}$ & $53 \pm 4.1 \mathrm{c}$ & - & - & - & - \\
\hline N1 & 188 & $25 \pm 5.4 \mathrm{~d}$ & $61 \pm 5.3 c$ & 102 & 13.3 & 32.4 & 54.3 \\
\hline N2 & 375 & $39 \pm 1.7 \mathrm{c}$ & $82 \pm 6.2 b$ & 254 & 10.4 & 21.9 & 67.7 \\
\hline N3 & 563 & $27 \pm 4.1 \mathrm{~d}$ & $75 \pm 9.1 b$ & 461 & 4.8 & 13.3 & 81.9 \\
\hline MN0 & 233 & $44 \pm 6.3 \mathrm{c}$ & $91 \pm 8.9 b$ & 98 & 18.8 & 39.1 & 42.1 \\
\hline MN1 & 421 & $75 \pm 3.2 b$ & $104 \pm 16.1 b$ & 242 & 17.7 & 55.3 & 57.4 \\
\hline MN2 & 608 & $96 \pm 3.0 \mathrm{a}$ & $127 \pm 21.3 \mathrm{a}$ & 385 & 15.6 & 33.9 & 63.3 \\
\hline $\mathrm{MN} 3$ & 796 & $150 \pm 10.7 b$ & $122 \pm 20.2 \mathrm{a}$ & 524 & 18.2 & 21.7 & 65.8 \\
\hline
\end{tabular}

Means of triplicates \pm SE. The same lowercase letters behind SE in the same volume indicate no significant difference between the two treatments at the 0.05 significance level.

${ }^{\text {z}}$ Treatment: N0, 0 kg N/ha; N1, 188 kg N/ha; N2, 375 kg N/ha; N3, 563 kg N/ha; MN0, 233 kg N/ha; MN1, 421 kg N/ha; MN2, 608 kg N/ha; MN3, 796 kg N/ha. ${ }^{{ }^{y}} \mathrm{~N}$ input $=$ urea $\mathrm{N}+$ manure $\mathrm{N}$.

${ }^{\mathrm{x}} \mathrm{N}$ absorption $=$ aboveground biomass $\mathrm{N}+$ accumulated tomato yield $\mathrm{N}$.

${ }^{\mathrm{w}} \mathrm{N}$ loss $=\mathrm{N}$ input $-\mathrm{N}$ absorption - accumulated soil $\mathrm{TN}$.

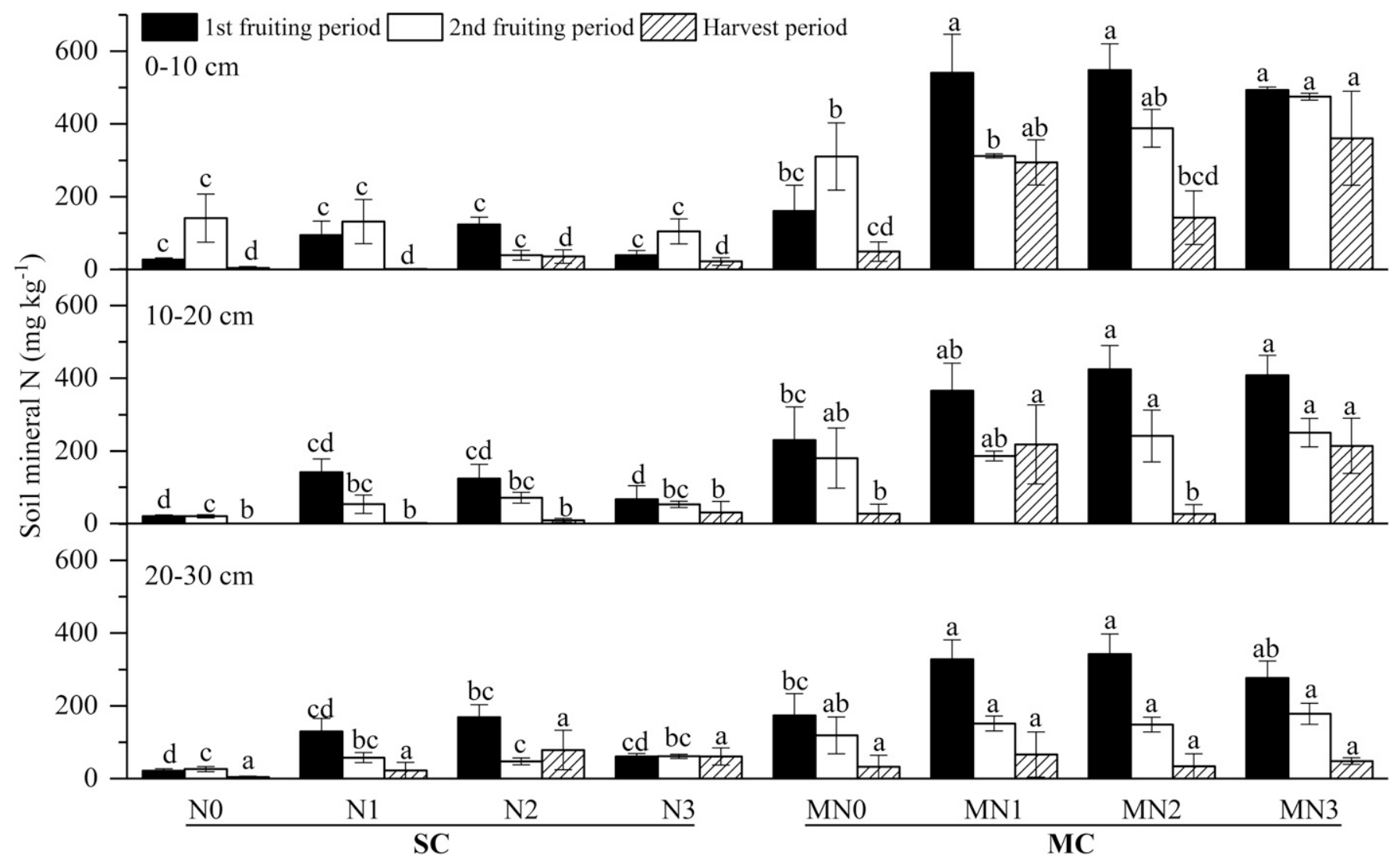

Fig. 2. Average contents of soil mineral $\mathrm{N}$ for three soil depths $(0-10,10-20$, and $20-30 \mathrm{~cm})$ during the period of tomato growth. Data are represented as plots of the mean of three replicate values. The vertical bars represent standard errors. Values with different lowercase letters within the same sampling times are

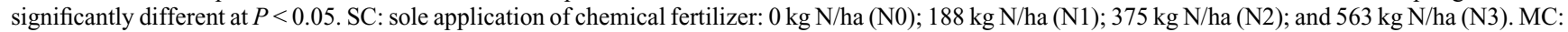
combined applications of manure with chemical N fertilizer: $233 \mathrm{~kg} \mathrm{~N} / \mathrm{ha}(\mathrm{MN} 0)$; $421 \mathrm{~kg} \mathrm{~N} / \mathrm{ha}(\mathrm{MN} 1)$; $608 \mathrm{~kg} \mathrm{~N} / \mathrm{ha}$ (MN2); and 796 kg N/ha (MN3). 
across the treatments, accounting for $4.8 \%$ to $18.8 \%$ of input $\mathrm{N}$ for all treatments (Table 2).

$N$ fraction content during the growth period. During the first fruiting period and second fruiting period, soil mineral $\mathrm{N}$ was the main pool of soil soluble $\mathrm{N}$ in all treatments $(53.1 \%$ to $57.2 \%$ and $52.8 \%$ to $67.5 \%$, respectively), whereas soil soluble organic $\mathrm{N}$ was the main pool of soil soluble $\mathrm{N}$ during the harvest period $(55.1 \%$ to $72.6 \%$ ). MC treatment had a more pronounced impact on soil mineral $\mathrm{N}$, soil soluble organic $\mathrm{N}$, soil fixed ammonium, and soil microbial biomass $\mathrm{N}(P<0.01)$ compared with SC treatment (Figs. 2-5). Soil mineral N, soil soluble organic $\mathrm{N}$, and soil fixed ammonium tended to be higher during the first fruiting period (Figs. 2-4), whereas soil microbial biomass $\mathrm{N}$ content tended to be higher during the second fruiting period (Fig. 5). Overall, soil mineral N, soil soluble organic $\mathrm{N}$, soil fixed ammonium, and soil microbial biomass $\mathrm{N}$ contents were higher in the soil at a depth of $0-10 \mathrm{~cm}$ than in soil at depths of $10-20$ and $20-30 \mathrm{~cm}(P<0.05)$ (Supplemental Table 1). On average, $\mathrm{N}$ fraction contents increased with the increasing $\mathrm{N}$ rate, peaking at $\mathrm{N} 2$ and MN2; this effect was significant for soil mineral $\mathrm{N}$, soil soluble organic $\mathrm{N}$, and soil microbial biomass $\mathrm{N}(P<0.05)$.

Stepwise regression analysis of $N$ fractions, tomato yield, and fruit composition during the growth period. The correlation analysis showed that soil mineral $\mathrm{N}$, soil soluble organic $\mathrm{N}$, soil fixed ammonium, soil microbial biomass $\mathrm{N}$, and tomato yield were positively correlated in a soil depth of 0-30 cm $(P<0.01)$ (Supplemental Table 2); however, except for soil mineral $\mathrm{N}$, there was no correlation with yield during the harvest period. The regression equation analysis showed that the effect of soil fixed ammonium on tomato yield was significantly negative during the first fruiting period at a depth of $0-10 \mathrm{~cm}$, whereas soil microbial biomass $\mathrm{N}$ had a significantly positive impact on tomato yield during the second fruiting and harvest periods at depths of $10-20 \mathrm{~cm}$ and $20-30 \mathrm{~cm}$, respectively (Table 3 ).

In general, soil mineral $\mathrm{N}$, soil soluble organic $\mathrm{N}$, soil fixed ammonium, and soil microbial biomass $\mathrm{N}$ were mainly correlated with soluble sugar and organic acid content (Supplemental Table 3). The regression equation showed that soil microbial biomass $\mathrm{N}$ had the most significant influence on fruit soluble sugar content during the second fruiting period. Soil fixed ammonium had the most significant influence on fruit organic acid content during the first fruiting period. Soil soluble organic $\mathrm{N}$ had the most significant influence on the soluble sugar/organic acid ratio during the first fruiting period (Table 4). During the harvest period, soil mineral $\mathrm{N}$ and soil soluble organic $\mathrm{N}$ had the most significant influence on vitamin $\mathrm{C}$ content. Soil fixed ammonium during the first and second fruiting periods and soil soluble organic $\mathrm{N}$ during the first fruiting period had the most significant influence on nitrate content (Table 4).

\section{Discussion}

Effects of fertilization on tomato yield, fruit composition, and $\mathrm{N}$ absorption

Tomato yield. Previous studies (de Ponti et al., 2012; Seufert et al., 2012; Willekens et al., 2014) have shown no significant difference in tomato yield between sole application of chemical fertilizer and combined manure-chemical $\mathrm{N}$ fertilizer applications. However, in our study, the tomato yield was lower with $\mathrm{MC}$ treatment than with SC treatments $(P>0.05)$ (Fig. 1A). This could be due to the following: 1) the use of manure with a slower release of readily available $\mathrm{N}$ and lower water use efficiency, leaf area index, and accumulated amount of dry matter (Jensen et al., 2010; Lovelli et al., 2012; Matsuda et al., 2011), thus leading to higher transpiration and increased stomata opening by the plants (Willekens et al., 2014); 2) immobilization of mineral $\mathrm{N}$ by soil microbes (Bonanomi et al., 2014), resulting in reduced availability of $\mathrm{N}$ for tomato; 3 ) plant growth limited

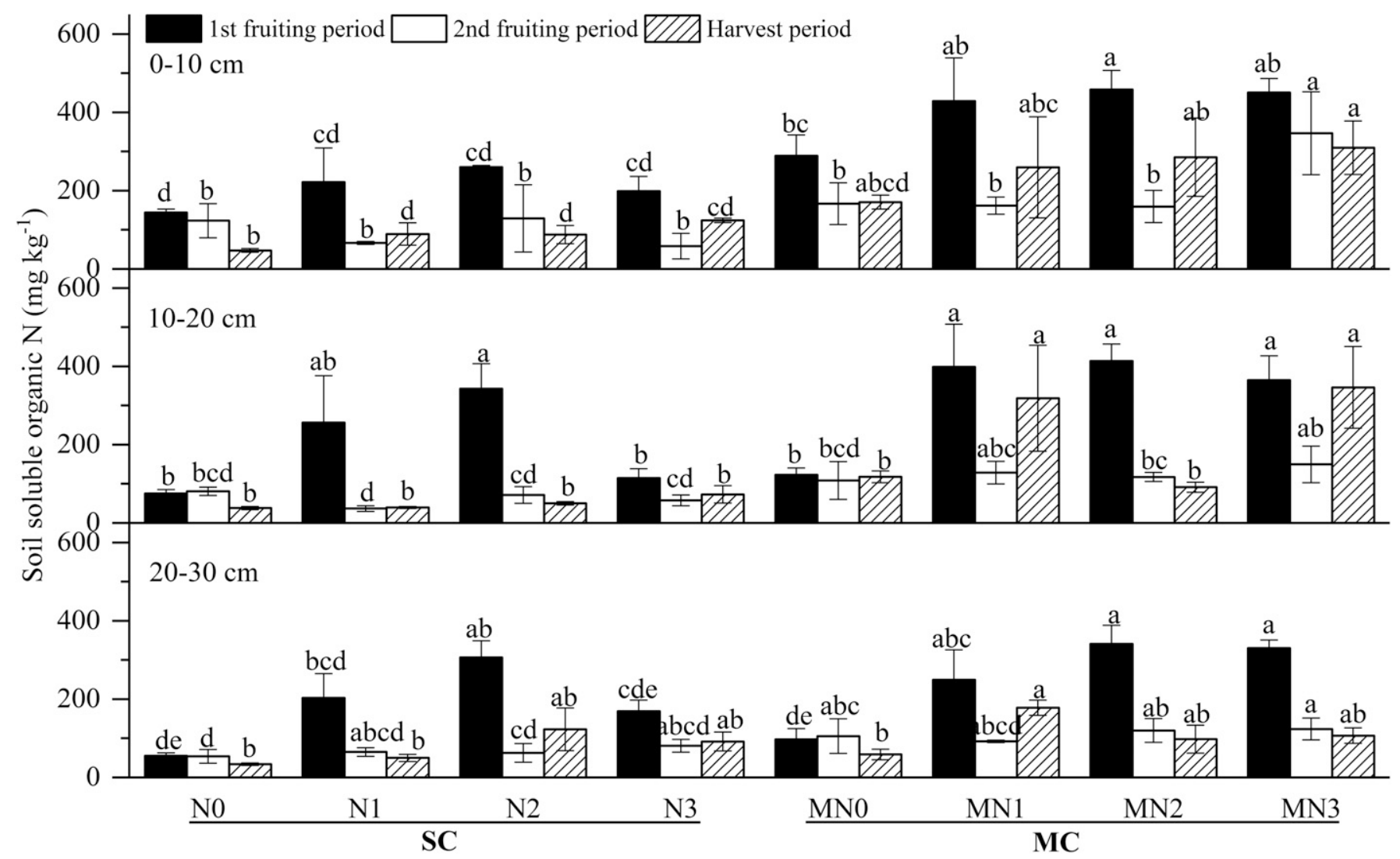

Fig. 3. Average contents of soil soluble organic $\mathrm{N}$ for three soil depths $(0-10,10-20$, and $20-30 \mathrm{~cm})$ during the period of tomato growth. Data are represented as plots of the mean of three replicate values. The vertical bars represent standard errors. Values with different lowercase letters within the same sampling times

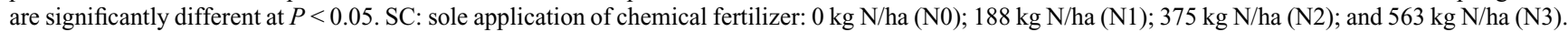
MC: combined applications of manure with chemical N fertilizer: $233 \mathrm{~kg} \mathrm{~N} / \mathrm{ha}(\mathrm{MN} 0) ; 421 \mathrm{~kg} \mathrm{~N} / \mathrm{ha}(\mathrm{MN} 1) ; 608 \mathrm{~kg} \mathrm{~N} / \mathrm{ha}$ (MN2); and 796 kg N/ha (MN3). 


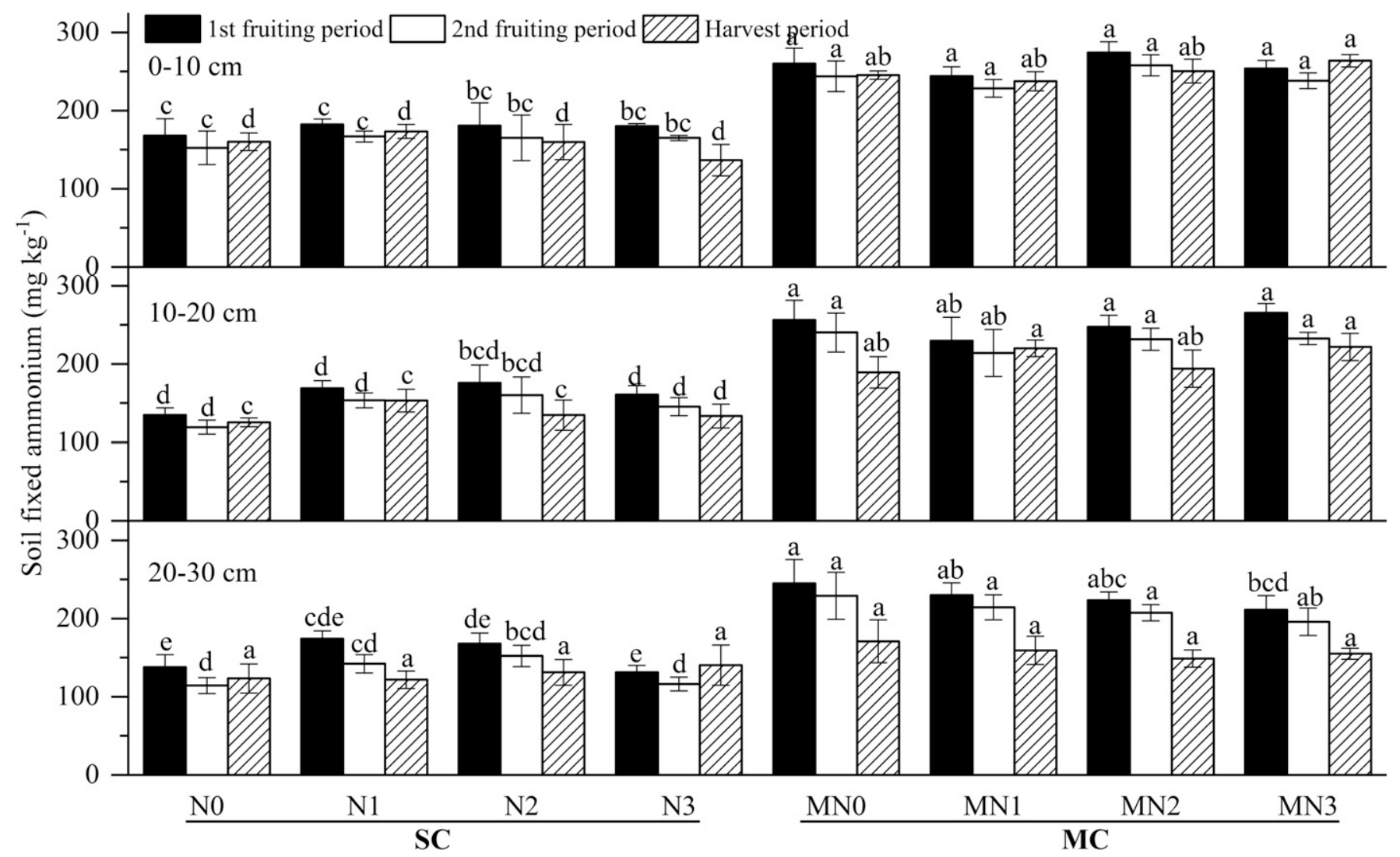

Fig. 4. Average contents of soil fixed ammonium for three soil depths $(0-10,10-20$, and $20-30 \mathrm{~cm})$ during the period of tomato growth. Data are represented as plots of the mean of three replicate values. The vertical bars represent standard errors. Values with different lowercase letters within the same

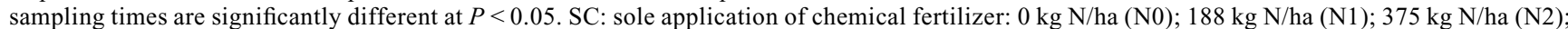
$563 \mathrm{~kg} \mathrm{~N} / \mathrm{ha}$ (N3). MC: combined applications of manure with chemical N fertilizer: $233 \mathrm{~kg} \mathrm{~N} / \mathrm{ha}(\mathrm{MN} 0) ; 421 \mathrm{~kg} \mathrm{~N} / \mathrm{ha}(\mathrm{MN} 1) ; 608 \mathrm{~kg} \mathrm{~N} / \mathrm{ha}(\mathrm{MN} 2) ;$ and $796 \mathrm{~kg} \mathrm{~N} / \mathrm{ha}(\mathrm{MN} 3)$.

by sulfur and phosphorus in the N-rich greenhouse soil (Heeb et al., 2006); and 4) chicken manure with a low C-to-N ratio used in the present study may have escalated the intensity of competition between plants and microbes for soil mineral $\mathrm{N}$ or soil soluble organic $\mathrm{N}$.

Fruit composition. The taste of tomato is largely determined by the soluble sugar and organic acid contents, and the ratio between the two (Kader, 2008), and represent more than half of the total dry matter in tomatoes (Ripoll et al., 2014). Additionally, in terms of tomato fruit composition, vitamin $\mathrm{C}$ is the most important antioxidant compound (Leiva-Brondo et al., 2012). Tests to assess composition indicated that MC treatments yielded higher vitamin $\mathrm{C}$ and soluble sugar contents compared with SC treatments $(P<$ 0.05) (Fig. 1). Manure releases nutrients more slowly than mineral fertilizers; therefore, plants supplied with manure as fertilizer often grow less rapidly compared with plants fertilized with readily available mineral nutrients. This slower growth might be reflected in reduced water content, leading to a higher content of fruit compounds, such as sugars and acids (Wang et al., 2015). In this context, it is also worth noting that the MN3 treatment was shown to reduce fruit nitrate content significantly compared with the N3 treatment. Nonetheless, the high levels of fruit composition (as evidenced by vitamin $\mathrm{C}$, soluble sugar, organic acid, and nitrate contents) yielded by the MN2 treatment could be explained by an uptake of organic $\mathrm{N}$ compounds. Therefore, it is possible that a combined application of manure with an appropriate chemical $\mathrm{N}$ fertilizer could have a positive impact on fruit composition.

$N$ absorption. Nitrogen balance is an indirect indicator used to quantify $\mathrm{N}$ leaching in agricultural ecosystems (Bosch-Serra et al., 2015). Many studies have shown that $30 \%$ to $77 \%$ of the annual $\mathrm{N}$ loss $/ \mathrm{N}$ input in a greenhouse system has been due to $\mathrm{N}$ surplus determined primarily by the input of exogenous $\mathrm{N}$ in relation to the output of $\mathrm{N}$ by crops (Ren et al., 2014). In general, it is difficult for plants to absorb soil mineral $\mathrm{N}$ and soil soluble organic $\mathrm{N}$ from depths below $30 \mathrm{~cm}$, but this depth zone is prone to leaching under the influence of irrigation water, thereby increasing the risk of groundwater pollution (Zhang et al., 2016). The N3 and MN3 treatments showed the highest annual rates of $\mathrm{N}$ loss during the 3-year greenhouse cultivation period, comprising $81.9 \%$ and $65.8 \%$ of the annual $\mathrm{N}$ input, respectively (Table 2). This finding indicated that excessive $\mathrm{N}$ input leads to a high accumulation of $\mathrm{N}$ below the root zone; this exceeds plant requirements and is subject to downward migration and leachingdominated loss.

\section{Dynamics of $\mathbf{N}$ fractions during the} tomato growth period

The $\mathrm{NH}_{4}{ }^{+}-\mathrm{N}$ content in greenhouse conditions is relatively stable and low in the soil profile throughout the growing season due to the high temperatures and nitrification (Chen et al., 2012; Ren et al., 2010). Therefore, the dynamic variation in soil mineral $\mathrm{N}$ in the greenhouse is mainly attributable to $\mathrm{NO}_{3}{ }^{-}-\mathrm{N}$ due to the faster turnover rate of $\mathrm{NH}_{4}{ }^{+}-\mathrm{N}$.

We observed that soil mineral $\mathrm{N}$, soil soluble organic $\mathrm{N}$, and soil fixed ammonium contents tended to be higher during the first fruiting period (Figs. 2-4). Soil microorganisms use soluble organic $\mathrm{C}$ and inorganic $\mathrm{N}$ to synthesize the amino acids and proteins required for life activities, and they decompose soil soluble organic $\mathrm{N}$ in soil after microbes die (Christou et al., 2005). At the start of the tomato growth period, a combination of the competition between the weak roots, suitable temperature $\left(23{ }^{\circ} \mathrm{C}\right)$, and sufficient moisture levels might have promoted these two microbial transformation processes when sufficient $\mathrm{C}$ and $\mathrm{N}$ sources were supplied (Farrell et al., 2011). Alternatively, $\mathrm{NO}_{3}{ }^{-}-\mathrm{N}$ and $\mathrm{NH}_{4}{ }^{+}-\mathrm{N}$ could have been released after urea application and through $\mathrm{N}$ mineralization during the early tomato growth period, and much of the soil soluble organic $\mathrm{N}$ that was derived from the newly applied chicken manure could have been derived from abiotic incorporation of excess $\mathrm{NO}_{3}{ }^{-}-\mathrm{N}$ in dissolved organic matter 


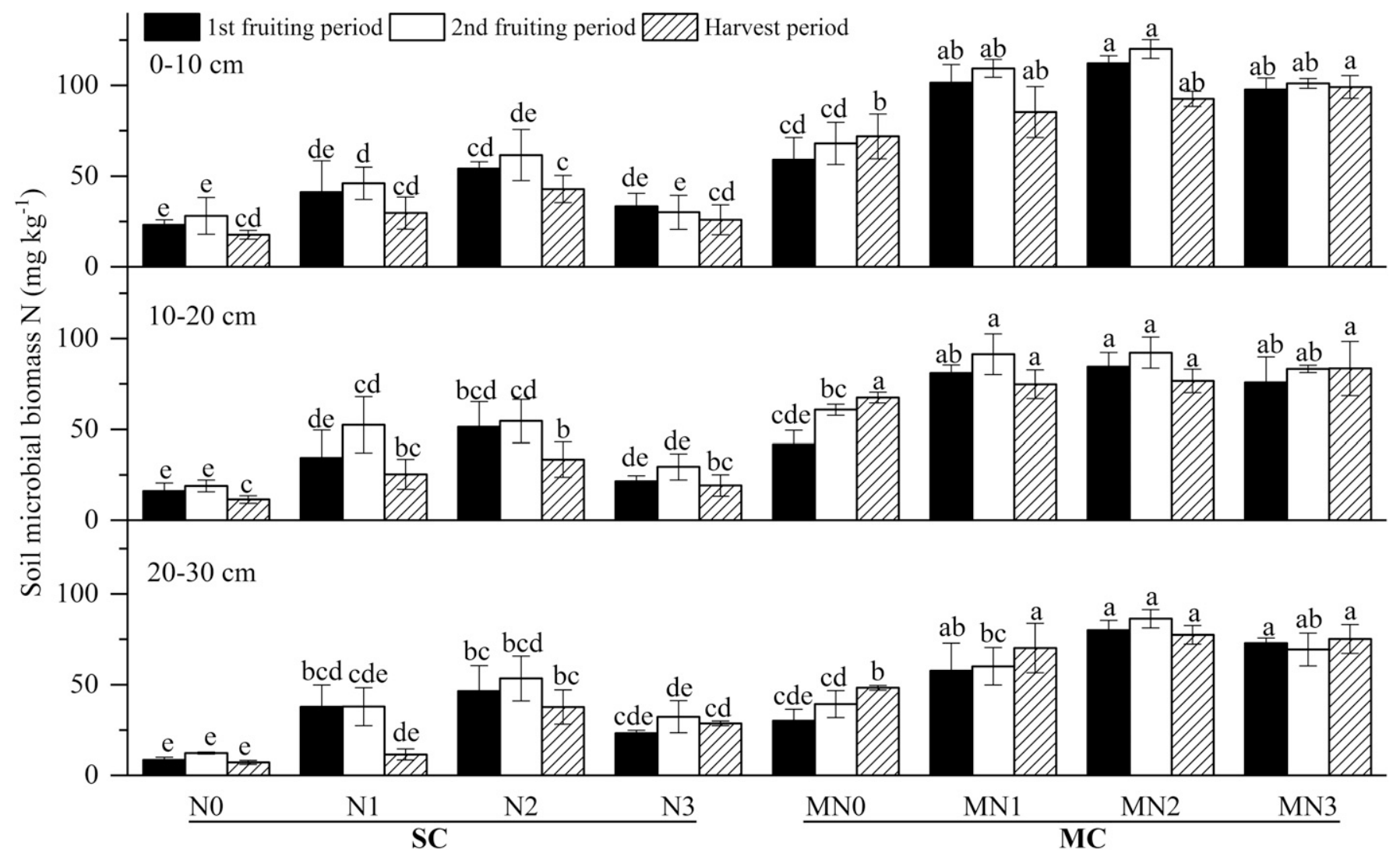

Fig. 5. Average contents of soil microbial biomass $\mathrm{N}$ for three soil depths $(0-10,10-20$, and $20-30 \mathrm{~cm})$ during the period of tomato growth. Data are represented as plots of the mean of three replicate values. The vertical bars represent standard errors. Values with different lowercase letters within the same sampling times

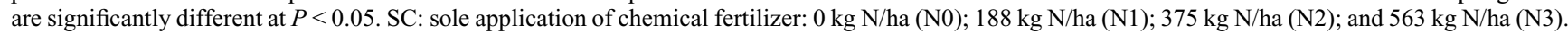
MC: combined applications of manure with chemical N fertilizer: $233 \mathrm{~kg} \mathrm{~N} / \mathrm{ha}$ (MN0); $421 \mathrm{~kg} \mathrm{~N} / \mathrm{ha}$ (MN1); $608 \mathrm{~kg} \mathrm{~N} / \mathrm{ha}$ (MN2); and 796 kg N/ha (MN3).

Table 3. Stepwise regression analysis between $\mathrm{N}$ fractions and fruit yield during the tomato growth period.

\begin{tabular}{ll}
\hline Soil layer & \multicolumn{1}{c}{ Optimum regression equation } \\
\hline $0-10 \mathrm{~cm}$ & $\mathrm{Y}=110058-101.3$ Soil fixed ammonium first fruiting period $\left(P<0.05 ; R^{2}=0.579\right)$ \\
$10-20 \mathrm{~cm}$ & $\mathrm{Y}=110512+130.7$ Soil microbial biomass $\mathrm{N}_{\text {second fruiting period }}\left(P<0.05 ; R^{2}=0.655\right)$ \\
$20-30 \mathrm{~cm}$ & $\mathrm{Y}=109808+155.8$ Soil microbial biomass $\mathrm{N}_{\text {harvest period }}\left(P<0.05 ; R^{2}=0.584\right)$ \\
\hline
\end{tabular}

(Fang et al., 2009). Additionally, in the Nrich greenhouse soil, the uptake by soil microorganisms of low-weight soil soluble organic $\mathrm{N}$ may primarily provide them with $\mathrm{C}$ to fuel respiration (Christou et al., 2005) rather than satisfy their internal $\mathrm{N}$ demand (Jones et al., 2004), resulting in the accumulation of soil soluble organic $\mathrm{N}$.

The soil microbial biomass $\mathrm{N}$ content peaked during the second fruiting period (Fig. 5). The aboveground and belowground plant biomass may quantitatively increase soil organic matter and qualitatively provide a variety of $\mathrm{C}$ substrates, which may increase soil microbial growth and activity (Spedding et al., 2004). Additionally, we increased the irrigation frequency in response to the high greenhouse temperatures (28 to $31{ }^{\circ} \mathrm{C}$ ) during the second fruiting period, resulting in fast mineralization and nitrification in the greenhouse soil (Lentz and Ippolito, 2012) and an increase in the rate at which soil organic matter decomposed. Sugihara et al. (2010) also showed that soil microbial biomass $\mathrm{N}$ and soil moisture contents are significantly positively correlated.
In addition, $\mathrm{NH}_{4}^{+}-\mathrm{N}$ was depleted in the rhizosphere $(0-20 \mathrm{~cm})$ soil solution, and the high nitrification rate triggered the release of soil fixed ammonium and reduction in fixation (Beuters et al., 2014), during which the increased microbial $\mathrm{N}$ uptake favored the release of soil fixed ammonium. Furthermore, soil mineral $\mathrm{N}$, soil fixed ammonium, and soil microbial biomass $\mathrm{N}$ contents were lower during the harvest period. This result may be explained by decreased root biomass, rhizodeposition, and poor irrigation during the stable growth period. According to Singh et al. (2007), $\mathrm{N}$ uptake during the maturation period leads to extreme $\mathrm{N}$ competition between plant and soil microbes, thereby keeping soil microbial biomass $\mathrm{N}$ levels low during this period. Additionally, due to the lower mineralization and nitrification during the period of intensive harvest, sources of soil mineral $\mathrm{N}$ and soil fixed ammonium are reduced.

Overall, the lowest soil mineral $\mathrm{N}$ content (due to plant and microbial $\mathrm{N}$ uptake) and, correspondingly, soil fixed ammonium content occurred during phases of increasing soil microbial biomass $\mathrm{N}$ under the greenhouse soil, proving that heterotrophic microflora favors the release of soil fixed ammonium as a consequence of increased microbial $\mathrm{N}$ uptake. The large dynamic variation in $\mathrm{N}$ fractions during the tomato growth period was probably mediated by the microbial demand.

\section{Effects of fertilization on $\mathbf{N}$ fractions}

In general, soil $\mathrm{N}$ is in equilibrium with microbes and the interlayered sites of clay minerals and soluble N. However, the application of externally supplied $\mathrm{N}$ can disturb this balance, thereby affecting soil $\mathrm{N}$ supply and the fate of applied N (Duan et al., 2017). In the present study, the $\mathrm{N}$ fraction contents were higher with the $\mathrm{MC}$ treatments than with the SC treatments, and they tended to be higher with all of the MN2 treatments. The current general consensus is that manure application leads to a substantial increase in soil $\mathrm{N}$ mineralization potential and enhances the activity of heterotrophic microorganisms in the added organic manure; subsequent turnover of this microbial population will lead to the production of $\mathrm{NH}_{4}{ }^{+}-\mathrm{N}$ (Bonkowski et al., 2000). Additionally, manure preserves a certain amount of mineral $\mathrm{N}$ and dissolved organic $\mathrm{N}$ (Khalili and Nourbakhsh, 2012), both of which are continuously released from the manure due to mineralization, thereby increasing the soil 
Table 4. Stepwise regression analysis between $\mathrm{N}$ fractions and tomato quality during the tomato growth period.

\begin{tabular}{|c|c|}
\hline Item & Optimum regression equation \\
\hline Soluble sugar & $\begin{array}{l}\mathrm{Y}_{0-10 \mathrm{~cm}}=3.8+0.002 \text { Soil fixed ammonium first fruiting period }\left(P<0.05 ; R^{2}=0.577\right) \\
\mathrm{Y}_{10-20 \mathrm{~cm}}=4.0+0.002 \text { Soil microbial biomass } \mathrm{N}_{\text {second fruiting period }}\left(P<0.05 ; R^{2}=0.509\right) \\
\mathrm{Y}_{20-30 \mathrm{~cm}}=4.0+0.003 \text { Soil microbial biomass } \mathrm{N}_{\text {second fruiting period }}\left(P<0.05 ; R^{2}=0.619\right)\end{array}$ \\
\hline Organic acid & $\begin{array}{l}\mathrm{Y}_{0-10 \mathrm{~cm}}=0.4+0.001 \text { Soil microbial biomass } \mathrm{N}_{\text {harvest period }}\left(P<0.05 ; R^{2}=0.623\right) \\
\mathrm{Y}_{10-20 \mathrm{~cm}}=0.4+0.001 \text { Soil fixed ammonium } \text { first fruiting period }\left(P<0.05 ; R^{2}=0.633\right) \\
\mathrm{Y}_{20-30 \mathrm{~cm}}=0.4+0.001 \text { Soil fixed ammonium } \text { first fruiting period }\left(P<0.05 ; R^{2}=0.687\right)\end{array}$ \\
\hline Soluble sugar/organic acid & $\begin{array}{l}\mathrm{Y}_{0-10 \mathrm{~cm}}=5.4+0.004 \text { Soil soluble organic } \mathrm{N}_{\text {first fruiting period }}\left(P<0.05 ; R^{2}=0.779\right) \\
-\end{array}$ \\
\hline Vitamin C & $\begin{array}{l}\mathrm{Y}_{0-10 \mathrm{~cm}}=9.4+0.006 \text { Soil mineral } \mathrm{N}_{\text {first fruiting period }}\left(P<0.05 ; R^{2}=0.802\right) \\
\mathrm{Y}_{10-20 \mathrm{~cm}}=9.3+0.006 \text { Soil soluble organic } \mathrm{N}_{\text {first fruiting period }}\left(P<0.05 ; R^{2}=0.765\right)\end{array}$ \\
\hline Nitrate & $\begin{array}{l}\mathrm{Y}_{0-10 \mathrm{~cm}}=55.1+0.547 \text { Soil fixed ammonium first fruiting period }\left(P<0.05 ; R^{2}=0.566\right) \\
\mathrm{Y}_{10-20 \mathrm{~cm}}=114.4+0.83 \text { Soil soluble organic } \mathrm{N}_{\text {first fruiting period }}\left(P<0.05 ; R^{2}=0.741\right) \\
\mathrm{Y}_{20-30 \mathrm{~cm}}=70.8+0.474 \text { Soil fixed ammonium }{ }_{\text {harvest period }}\left(P<0.05 ; R^{2}=0.582\right)\end{array}$ \\
\hline
\end{tabular}

mineral $\mathrm{N}$, soil fixed ammonium, and soil soluble organic $\mathrm{N}$ contents. As a source of energy for soil microbes, organic carbon promotes increases in the number of soil microorganisms and has a significantly positive correlation with the soil soluble organic $\mathrm{N}$ content (Huang et al., 2014; Liang et al., 2011; Xing et al., 2010; Yang et al., 2012).

In the present study, $\mathrm{N}$ fraction contents increased with the increasing $\mathrm{N}$ rate, up to N2 ( $375 \mathrm{~kg} \mathrm{~N} / \mathrm{ha}$ ), regardless of whether manure application treatments were used, which could be explained by the nutrients required of $\mathrm{N}$ by soil microorganisms and crops for growth (Abaas et al., 2012), and mineralization increased after the addition of $\mathrm{N}$. However, the higher application rate of $\mathrm{N}$ fertilizer inhibited the growth of soil microorganisms as a result of $\mathrm{NO}_{3}{ }^{-}-\mathrm{N}$ accumulation, lower soil $\mathrm{pH}$, and accumulation of recalcitrant compounds and potential $\mathrm{N}$ saturation, which is usually a negative effect of urea fertilizers (Janssens et al., 2010); these factors lead to decreased $\mathrm{N}$ fractions, as reported by Shen et al. (2010), who performed a greenhouse study.

In soils with a high ammonium fixation capacity, at least part of the $\mathrm{NH}_{4}{ }^{+}-\mathrm{N}$ supplied as fertilizer may be bound in clay mineral interlayers (Yan et al., 2008). However, in our study, no significant difference in the soil fixed ammonium content in response to the $\mathrm{N}$ rate was observed (Fig. 4), indicating that the proportions of urea-N entering the soil fixed ammonium pools were low, which was consistent with previous studies (Luce et al., 2014; Quan et al., 2016). The soil fixed ammonium content is known to depend on the degree of $\mathrm{K}$ saturation of the interlayers in $2: 1$ clay mineral. The low urea- $\mathrm{N}$ recovery in the soil fixed ammonium pool could be a result of the high rate of fertilization $(>375 \mathrm{~kg}$ $\mathrm{N} /$ ha) during greenhouse cultivation blocking sufficient $\mathrm{K}^{+}$and $\mathrm{NH}_{4}^{+}$. DeForest et al. (2004) observed that high external $\mathrm{N}$ input may exceed plant growth demand, potentially causing ecosystem $\mathrm{N}$ saturation, resulting in a similar maximum capacity of ammonium fixation.

Our results demonstrated that the adoption of a soil treatment strategy involving 3 years of treatment with manure and inorganic $\mathrm{N}$ fertilizer increases the $\mathrm{N}$ fraction in green- house soil, especially in the surface layers. Such a mineralization-immobilization turnover of supplemented fertilizer, especially via organic sources, contributes substantially to the availability of $\mathrm{N}$ for tomato and soil microbes and, consequently, to their growth.

\section{Stepwise regression analysis of $\mathbf{N}$ fraction, tomato yield, and fruit composition}

In the present study, an optimum regression equation comparing $\mathrm{N}$ fractions with tomato yield and fruit composition showed that soil fixed ammonium during the first fruiting period had a negative significant effect on tomato yield, but a positive significant effect on fruit composition (Table 3 ). As already mentioned, soil mineral $\mathrm{N}$, soil soluble organic $\mathrm{N}$, and soil fixed ammonium contents were higher during the first fruiting period. However, due to the highly complex molecules (aromatic structures and complex molecules) that account for the larger proportion of soil soluble organic N (Tian et al., 2012) and the $\mathrm{NH}_{4}^{+}-\mathrm{N}$, which is readily taken-up by plants, soil fixed ammonium was released and taken-up by plants. Dou and Steffens (1995) showed that $90 \%$ to $95 \%$ of soil fixed ammonium had been produced during a 14-week period in soil planted with perennial ryegrass (Lolium perenne L.) under greenhouse conditions. The effects of soil microbial biomass $\mathrm{N}$ on tomato yield and fruit composition were positively significant during the second fruiting and harvest periods. It is possible that $\mathrm{N}$ immobilized (fertilizer $\mathrm{N}$, native soil $\mathrm{N}$ ) by microbes may contribute much $\mathrm{N}$, which is available for a long period of time, to subsequent plant uptake due to the higher soil microbial biomass $\mathrm{N}$ content occurring during the second fruiting period.

\section{Conclusions}

Our study has provided evidence of an appropriate agricultural management strategy for tomato cultivation to help balance yield, $\mathrm{N}$ fractions, and fruit composition. The results showed that the MN2 treatment resulted in higher $\mathrm{N}$ fraction contents and total tomato yield, and it had a positive effect on fruit composition. Additionally, the risk of
$\mathrm{N}$ loss increased with the increasing $\mathrm{N}$ rate. We found that the soil fixed ammonium during the first fruiting period and soil microbial biomass $\mathrm{N}$ during the second fruiting period had a more significant influence on tomato yield and fruit composition, possibly as a result of the uptake of available $\mathrm{N}$ compounds. In the context of the agricultural requirement for an appropriate tradeoff between $\mathrm{N}$ fractions and yield, and for comprehensive fruit composition, $\mathrm{MC}$ treatment at an appropriate rate $(\mathrm{MN} 2: 608 \mathrm{~kg} \mathrm{~N} / \mathrm{ha}$ ) was shown to be the best management strategy for greenhouse cultivation of tomato in northeast China.

\section{Literature Cited}

Abaas, E., P. Hill, P. Roberts, D. Murphy, and D. Jones. 2012. Microbial activity differentially regulates the vertical mobility of nitrogen compounds in soil. Soil Biol. Biochem. 53:120-123.

Al-Amri, S.M. 2013. Improved growth, productivity and quality of tomato (Solanum lycopersicum L.) plants through application of shikimic acid. Saudi J. Biol. Sci. 20:339-345.

Beuters, P., T. Eichert, and H. Scherer. 2014. Influence of pre-crop and root architecture on the mobilization of non-exchangeable $\mathrm{NH}_{4}{ }^{+}$. Plant Soil Environ. 8:372-378.

Bonanomi, G., R. D'Ascoli, R. Scotti, S. Gaglione, M.G. Caceres, S. Sultana, R. Scelza, M. Rao, and A. Zoina. 2014. Soil quality recovery and crop yield enhancement by combined application of compost and wood to vegetables grown under plastic tunnels. Agric. Ecosyst. Environ. 192:1-7.

Bonkowski, M., B. Griffiths, and C. Scrimgeour. 2000. Substrate heterogeneity and microfauna in soil organic 'hotspots' as determinants of nitrogen capture and growth of ryegrass. Appl. Soil Ecol. 14:37-53.

Bosch-Serra, A.D., C. Ortiz, M.R. Yagüe, and J. Boixadera. 2015. Strategies to optimize nitrogen efficiency when fertilizing with pig slurries in dryland agricultural systems. Eur. J. Agron. 67:27-36.

Bremner, J. and D. Keeney. 1966. Determination and isotope-ratio analysis of different forms of nitrogen in soils: Exchangeable ammonium, nitrate, and nitrite by extraction-distillation methods. Soil Sci. Soc. Amer. J. 30:577-582.

Brookes, P.C., A. Landman, G. Pruden, and D. Jenkinson. 1985. Chloroform fumigation and the release of soil nitrogen: A rapid direct extraction method to measure microbial biomass 
nitrogen in soil. Soil Biol. Biochem. 17:837842.

Chen, J., S. Kang, T. Du, R. Qiu, P. Guo, and R. Chen. 2013. Quantitative response of greenhouse tomato yield and quality to water deficit at different growth stages. Agr. Water Mgt. 129:152-162.

Chen, Q.H., Y. Feng, Y.P. Zhang, Q.C. Zhang, I.H. Shamsi, Y.S. Zhang, and X.Y. Lin. 2012. Short-term responses of nitrogen mineralization and microbial community to moisture regimes in greenhouse vegetable soils. Pedosphere 22:263-272.

Christou, M., E.J. Avramides, J.P. Roberts, and D.L. Jones. 2005. Dissolved organic nitrogen in contrasting agricultural ecosystems. Soil Biol. Biochem. 37:1560-1563.

de Ponti, T., B. Rijk, and M.K. Van Ittersum. 2012. The crop yield gap between organic and conventional agriculture. Agr. Syst. 108:1-9.

DeForest, J.L., D.R. Zak, K.S. Pregitzer, and A.J. Burton. 2004. Atmospheric nitrate deposition, microbial community composition, and enzyme activity in northern hardwood forests. Soil Sci. Soc. Amer. J. 68:132-138.

Dou, H. and D. Steffens. 1995. Recovery of ${ }^{15} \mathrm{~N}$ labelled urea as affected by fixation of ammonium by clay minerals. Zeitschrift für Pflanzenernährung und Bodenkunde 158:351-354.

Duan, P., Y. Zhang, Y. Cong, W. Xu, N. Yu, and Y. Zhang. 2017. The dynamics of soil soluble nitrogen and soil retained nitrogen in greenhouse soil. Acta Agriculturae Scandinavica, Section B - Soil \& Plant Sci. 67:51-61.

Erba, D., M.C. Casiraghi, A. Ribas-Agustí, R. Cáceres, O. Marfâ, and M. Castellari. 2013. Nutritional value of tomatoes (Solanum lycopersicum L.) grown in greenhouse by different agronomic techniques. J. Food Compos. Anal. 31:245-251.

Fang, Y., W. Zhu, P. Gundersen, J. Mo, G. Zhou, and M. Yoh. 2009. Large loss of dissolved organic nitrogen from nitrogen-saturated forests in subtropical China. Ecosystems 12:3345.

Farrell, M., P.W. Hill, J. Farrar, R.D. Bardgett, and D.L. Jones. 2011. Seasonal variation in soluble soil carbon and nitrogen across a grassland productivity gradient. Soil Biol. Biochem. 43:835-844.

García-Robledo, E., A. Corzo, and S. Papaspyrou. 2014. A fast and direct spectrophotometric method for the sequential determination of nitrate and nitrite at low concentrations in small volumes. Mar. Chem. 162:30-36.

Ge, T., S.a. Nie, H. Qin, H. Xiao, and C. Tong. 2012. Microcalorimetric studies for microbial activity of three vegetable soils. J. Food Agr. Environ. 10:930-932.

Ge, T.D., S.W. Song, P. Roberts, D.L. Jones, D.F. Huang, and K. Iwasaki. 2009. Amino acids as a nitrogen source for tomato seedlings: The use of dual-labeled (C-13, N-15) glycine to test for direct uptake by tomato seedlings. Environ. Expt. Bot. 66:357-361.

Gouveia, G.A. and G.D. Eudoxie. 2007. Distribution of fertiliser $\mathrm{N}$ among fixed ammonium fractions as affected by moisture and fertiliser source and rate. Biol. Fertil. Soils 44:9-18.

Heeb, A., B. Lundegårdh, G. Savage, and T. Ericsson. 2006. Impact of organic and inorganic fertilizers on yield, taste, and nutritional quality of tomatoes. J. Plant Nutr. Soil Sci. 169:535-541.

Huang, C.Y., S.H. Jien, T.H. Chen, G.L. Tian, and C.Y. Chiu. 2014. Soluble organic $\mathrm{C}$ and $\mathrm{N}$ and their relationships with soil organic $\mathrm{C}$ and $\mathrm{N}$ and microbial characteristics in moso bamboo
(Phyllostachys edulis) plantations along an elevation gradient in Central Taiwan. J. Soils Sediments 14:1061-1070.

Jamtgard, S., T. Nasholm, and K. Huss-Danell. 2010. Nitrogen compounds in soil solutions of agricultural land. Soil Biol. Biochem. 42:23252330 .

Janssens, I., W. Dieleman, S. Luyssaert, J.A. Subke, M. Reichstein, R. Ceulemans, P. Ciais, A.J. Dolman, J. Grace, and G. Matteucci. 2010. Reduction of forest soil respiration in response to nitrogen deposition. Nat. Geosci. 3:315-322.

Jensen, C.R., A. Battilani, F. Plauborg, G. Psarras, K. Chartzoulakis, F. Janowiak, R. Stikic, Z. Jovanovic, G. Li, and X. Qi. 2010. Deficit irrigation based on drought tolerance and root signalling in potatoes and tomatoes. Agr. Water Mgt. 98:403-413.

Jones, D.L., J.R. Healey, V.B. Willett, J.F. Farrar, and A. Hodge. 2005. Dissolved organic nitrogen uptake by plants - an important $\mathrm{N}$ uptake pathway? Soil Biol. Biochem. 37:413-423.

Jones, D.L., A. Hodge, and Y. Kuzyakov. 2004. Plant and mycorrhizal regulation of rhizodeposition. New Phytol. 163:459-480.

Kader, A.A. 2008. Flavor quality of fruits and vegetables. J. Sci. Food Agr. 88:1863-1868.

Khalili, B. and F. Nourbakhsh. 2012. Vertical distribution of soluble organic nitrogen, nitrogen mineralization, nitrification, and amidohydrolase activities in a manure-treated soil. J. Plant Nutr. Soil Sci. 175:265-272.

Kirchmann, H. and L. Bergström. 2001. Do organic farming practices reduce nitrate leaching? Commun. Soil Sci. Plant Anal. 32:997-1028.

Kuscu, H., A. Turhan, N. Ozmen, P. Aydinol, and A.O. Demir. 2014. Optimizing levels of water and nitrogen applied through drip irrigation for yield, quality, and water productivity of processing tomato (Lycopersicon esculentum Mill.). Hort. Environ. Biotechnol. 55:103-114.

Kuzyakov, Y. and X. Xu. 2013. Competition between roots and microorganisms for nitrogen: Mechanisms and ecological relevance. New Phytol. 198:656-669.

Leiva-Brondo, M., M. Valcárcel, C. Cortés-Olmos, S. Roselló, J. Cebolla-Cornejo, and F. Nuez. 2012. Exploring alternative germplasm for the development of stable high vitamin $\mathrm{C}$ content in tomato varieties. Scientia Hort. 133:84-88.

Lentz, R.D. and J.A. Ippolito. 2012. Biochar and manure affect calcareous soil and corn silage nutrient concentrations and uptake. J. Environ. Qual. 41:1033-1043.

Leyva, A., A. Quintana, M. Sánchez, E.N. Rodríguez, J. Cremata, and J.C. Sánchez. 2008. Rapid and sensitive anthrone-sulfuric acid assay in microplate format to quantify carbohydrate in biopharmaceutical products: Method development and validation. Biologicals 36:134-141.

Li, S.X., Z.H. Wang, and B.A. Stewart. 2013. Responses of crop plants to ammonium and nitrate N, p. 205-397. In: D.L. Sparks (ed.). Advances in Agronomy. Vol 118. Elsevier Academic Press Inc, San Diego.

Liang, B., X.Y. Yang, X.H. He, and J.B. Zhou. 2011. Effects of 17-year fertilization on soil microbial biomass $\mathrm{C}$ and $\mathrm{N}$ and soluble organic $\mathrm{C}$ and $\mathrm{N}$ in loessial soil during maize growth. Biol. Fertil. Soils 47:121-128.

Liu, W., H. Yang, J. Liu, L.B. Azevedo, X. Wang, Z. Xu, K. Abbaspour, and R. Schulin. 2016. Global assessment of nitrogen losses and tradeoffs with yields from major crop cultivations. Sci. Total Environ 572:526-537.

Lovelli, S., A. Scopa, M. Perniola, T. Di Tommaso, and A. Sofo. 2012. Abscisic acid root and leaf concentration in relation to biomass partitioning in salinized tomato plants. J. Plant Physiol. 169:226-233.

Luce, M.S., J.K. Whalen, N. Ziadi, B.J. Zebarth, and M.H. Chantigny. 2014. Labile organic nitrogen transformations in clay and sandyloam soils amended with 15 N-labelled faba bean and wheat residues. Soil Biol. Biochem. 68:208-218.

Masaka, J., M. Wuta, J. Nyamangara, and F.T. Mugabe. 2013. Effect of manure quality on nitrate leaching and groundwater pollution in wetland soil under field tomato (Lycopersicon esculentum, Mill var. Heinz) rape (Brassica napus, L var. Giant). Nutr. Cycl. Agroecosyst. 96:149-170.

Matsuda, R., K. Suzuki, A. Nakano, T. Higashide, and M. Takaichi. 2011. Responses of leaf photosynthesis and plant growth to altered source-sink balance in a Japanese and a Dutch tomato cultivar. Scientia Hort. 127:520-527.

Nieder, R., D.K. Benbi, and H.W. Scherer. 2011. Fixation and defixation of ammonium in soils: A review. Biol. Fertil. Soils 47:1-14

Paungfoo-Lonhienne, C., T.G. Lonhienne, D. Rentsch, N. Robinson, M. Christie, R.I. Webb, H.K. Gamage, B.J. Carroll, P.M. Schenk, and S. Schmidt. 2008. Plants can use protein as a nitrogen source without assistance from other organisms. Proc. Natl. Acad. Sci. USA 105: 4524-4529.

Quan, Z., B. Huang, C. Lu, Y. Shi, X. Chen, H. Zhang, and Y. Fang. 2016. The fate of fertilizer nitrogen in a high nitrate accumulated agricultural soil. Sci. Rpt. 5:21539.

Quan, Z., C. Lu, Y. Shi, X. Chen, B. Huang, Y. Wang, Y. Zhao, and J. Ma. 2015. Manure increase the leaching risk of soil extractable organic nitrogen in intensively irrigated greenhouse vegetable cropping systems. Acta Agriculturae Scandinavica, Section B-Soil \& Plant Sci. 65:199-207.

Ren, T., P. Christie, J.H. Wang, Q. Chen, and F.S. Zhang. 2010. Root zone soil nitrogen management to maintain high tomato yields and minimum nitrogen losses to the environment. Scientia Hort. 125:25-33.

Ren, T., J. Wang, Q. Chen, F. Zhang, and S. Lu. 2014. The effects of manure and nitrogen fertilizer applications on soil organic carbon and nitrogen in a high-input cropping system. PLoS One 9:e97732.

Ripoll, J., L. Urban, M. Staudt, F. Lopez-Lauri, L.P. Bidel, and N. Bertin. 2014. Water shortage and quality of fleshy fruits - making the most of the unavoidable. J. Expt. Bot. 65:4097-4117.

Seufert, V., N. Ramankutty, and J.A. Foley. 2012. Comparing the yields of organic and conventional agriculture. Nature 485:229-232.

Sharifi, M., B. Zebarth, D. Burton, C. Grant, and J. Cooper. 2007. Evaluation of some indices of potentially mineralizable nitrogen in soil. Soil Sci. Soc. Amer. J. 71:1233-1239.

Shen, J.P., L.M. Zhang, J.F. Guo, J.L. Ray, and J.Z. He. 2010. Impact of long-term fertilization practices on the abundance and composition of soil bacterial communities in Northeast China. Appl. Soil Ecol. 46:119-124.

Singh, S., N. Ghoshal, and K. Singh. 2007. Variations in soil microbial biomass and crop roots due to differing resource quality inputs in a tropical dryland agroecosystem. Soil Biol. Biochem. 39:76-86.

Soper, F.M., C. Paungfoo-Lonhienne, R. Brackin, D. Rentsch, S. Schmidt, and N. Robinson. 2011. Arabidopsis and Lobelia anceps access small peptides as a nitrogen source for growth. Funct. Plant Biol. 38:788-796. 
Spedding, T., C. Hamel, G. Mehuys, and C. Madramootoo. 2004. Soil microbial dynamics in maize-growing soil under different tillage and residue management systems. Soil Biol. Biochem. 36:499-512.

Stålnacke, P., P.A. Aakerøy, G. Blicher-Mathiesen, A. Iital, V. Jansons, J. Koskiaho, K. Kyllmar, A. Lagzdins, A. Pengerud, and A. Povilaitis. 2014. Temporal trends in nitrogen concentrations and losses from agricultural catchments in the Nordic and Baltic countries. Agr. Ecosyst. Environ. 198:94-103.

Sugihara, S., S. Funakawa, M. Kilasara, and T. Kosaki. 2010. Effect of land management and soil texture on seasonal variations in soil microbial biomass in dry tropical agroecosystems in Tanzania. Appl. Soil Ecol. 44:80-88.

Thomas, R.L., R.W. Sheard, and J.R. Moyer. 1967. Comparison of conventional and automated procedures for nitrogen, phosphorus, and potassium analysis of plant material using a dingle figestion. Agron. J. 59:240-243.

Tian, J., M. Fan, J. Guo, P. Marschner, X. Li, and Y. Kuzyakov. 2012. Effects of land use in- tensity on dissolved organic carbon properties and microbial community structure. Eur. J. Soil Biol. 52:67-72.

Vance, E., P. Brookes, and D. Jenkinson. 1987. An extraction method for measuring soil microbial biomass C. Soil Biol. Biochem. 19:703-707.

Vogeler, I., A. Blard, and N. Bolan. 2007. Modelling DCD effect on nitrate leaching under controlled conditions. Soil Res. 45:310-317.

Wang, C., F. Gu, J. Chen, H. Yang, J. Jiang, T. Du, and J. Zhang. 2015. Assessing the response of yield and comprehensive fruit quality of tomato grown in greenhouse to deficit irrigation and nitrogen application strategies. Agr. Water Mgt. 161:9-19.

Wang, Q., F. Li, E. Zhang, G. Li, and M. Vance. 2012. The effects of irrigation and nitrogen application rates on yield of spring wheat (longfu-920), and water use efficiency and nitrate nitrogen accumulation in soil. Austral. J. Crop Sci. 6:662.

Willekens, K., B. Vandecasteele, D. Buchan, and S. De Neve. 2014. Soil quality is positively affected by reduced tillage and compost in an intensive vegetable cropping system. Appl. Soil Ecol. 82:61-71.

Xing, S.H., C.R. Chen, B.Q. Zhou, H. Zhang, Z.M. Nang, and Z.H. Xu. 2010. Soil soluble organic nitrogen and active microbial characteristics under adjacent coniferous and broadleaf plantation forests. J. Soils Sediments 10:748-757.

Yan, T., W. Xiao-Zhi, Z. Hai-Tao, and F. Ke. 2008. Effect of potassium and $\mathrm{C} / \mathrm{N}$ ratios on conversion of $\mathrm{NH}_{4}{ }^{+}$in soils. Pedosphere 18:539-544.

Yang, K., J.J. Zhu, Q.L. Yan, and J.X. Zhang. 2012. Soil enzyme activities as potential indicators of soluble organic nitrogen pools in forest ecosystems of Northeast China. Ann. For. Sci. 69: 795-803.

Yoo, G. and M.M. Wander. 2008. Tillage effects on aggregate turnover and sequestration of particulate and humified soil organic carbon. Soil Sci. Soc. Amer. J. 72:670-676.

Zhang, H., Y. Zhang, C. Yan, E. Liu, and B. Chen. 2016. Soil nitrogen and its fractions between long-term conventional and no-tillage systems with straw retention in dryland farming in northern China. Geoderma 269:138-144. 
Supplemental Table 1. Repeat Measures ANOVA on N fractions in the $0-10,10-20$, and 20-30 $\mathrm{cm}$ soil layers in the sampling times in different application rates of $\mathrm{N}$ fertilizer.

\begin{tabular}{|c|c|c|c|c|}
\hline & Soil mineral $\mathrm{N}$ & Soil soluble organic $\mathrm{N}$ & Soil fixed ammonium & Soil microbial biomass $\mathrm{N}$ \\
\hline Treatments & $* *$ & $*$ & NS & $* *$ \\
\hline Sampling times & $* *$ & ** & $* *$ & $*$ \\
\hline Depth & $* *$ & ** & NS & $* *$ \\
\hline Treatments $\times$ Sampling times & $* *$ & $*$ & NS & $*$ \\
\hline Treatments $\times$ Depth & NS & NS & NS & NS \\
\hline Sampling times $\times$ Depth & NS & NS & ** & NS \\
\hline Treatments $\times$ Sampling times $\times$ Depth & NS & NS & NS & NS \\
\hline
\end{tabular}

Ns, *, **Nonsignificant or significant at $P<0.05$ or 0.01 , respectively.

Supplemental Table 2. Correlation coefficient of $\mathrm{N}$ fractions and tomato yield during the tomato growth period.

\begin{tabular}{|c|c|c|c|c|c|c|c|c|c|c|c|c|}
\hline \multirow[b]{2}{*}{ Soil layer } & \multicolumn{4}{|c|}{ 1st fruiting period } & \multicolumn{4}{|c|}{ 2nd fruiting period } & \multicolumn{4}{|c|}{ Harvest period } \\
\hline & $\begin{array}{c}\text { Soil } \\
\text { mineral N }\end{array}$ & $\begin{array}{c}\text { Soil } \\
\text { soluble } \\
\text { organic N }\end{array}$ & $\begin{array}{l}\text { Soil fixed } \\
\text { ammonium }\end{array}$ & $\begin{array}{c}\text { Soil } \\
\text { microbial } \\
\text { biomass } \mathrm{N}\end{array}$ & $\begin{array}{c}\text { Soil } \\
\text { mineral N }\end{array}$ & $\begin{array}{c}\text { Soil } \\
\text { soluble } \\
\text { organic N }\end{array}$ & $\begin{array}{c}\text { Soil fixed } \\
\text { ammonium }\end{array}$ & $\begin{array}{c}\text { Soil } \\
\text { microbial } \\
\text { biomass } \mathrm{N}\end{array}$ & $\begin{array}{c}\text { Soil } \\
\text { mineral N }\end{array}$ & $\begin{array}{c}\text { Soil } \\
\text { soluble } \\
\text { organic N }\end{array}$ & $\begin{array}{l}\text { Soil fixed } \\
\text { ammonium }\end{array}$ & $\begin{array}{c}\text { Soil } \\
\text { microbial } \\
\text { biomass } \mathrm{N}\end{array}$ \\
\hline $0-10 \mathrm{~cm}$ & $0.80^{* *}$ & $0.85^{\text {** }}$ & $0.79^{\text {** }}$ & $0.87^{\text {** }}$ & $0.70^{*}$ & 0.56 & $0.79^{* *}$ & $0.89^{\text {** }}$ & 0.54 & $0.84^{* *}$ & $0.75^{*}$ & $0.82^{* *}$ \\
\hline $10-20 \mathrm{~cm}$ & $0.83^{\text {** }}$ & $0.79^{\text {** }}$ & $0.74^{*}$ & $0.89^{\text {** }}$ & $0.80^{\text {*** }}$ & 0.60 & $0.76^{*}$ & $0.86^{\text {** }}$ & 0.21 & 0.32 & $0.68^{*}$ & $0.80^{\text {** }}$ \\
\hline $20-30 \mathrm{~cm}$ & $0.87^{* *}$ & $0.71^{*}$ & $0.73^{*}$ & $0.86^{\text {** }}$ & $0.71^{*}$ & $0.75^{*}$ & $0.74^{*}$ & $0.91^{\text {** }}$ & 0.39 & 0.41 & 0.46 & $0.82^{* *}$ \\
\hline
\end{tabular}

*, **Significant at $P<0.05$ or 0.01 , respectively.

Supplemental Table 3. Correlation coefficient of $\mathrm{N}$ fractions and tomato quality during the tomato growth period.

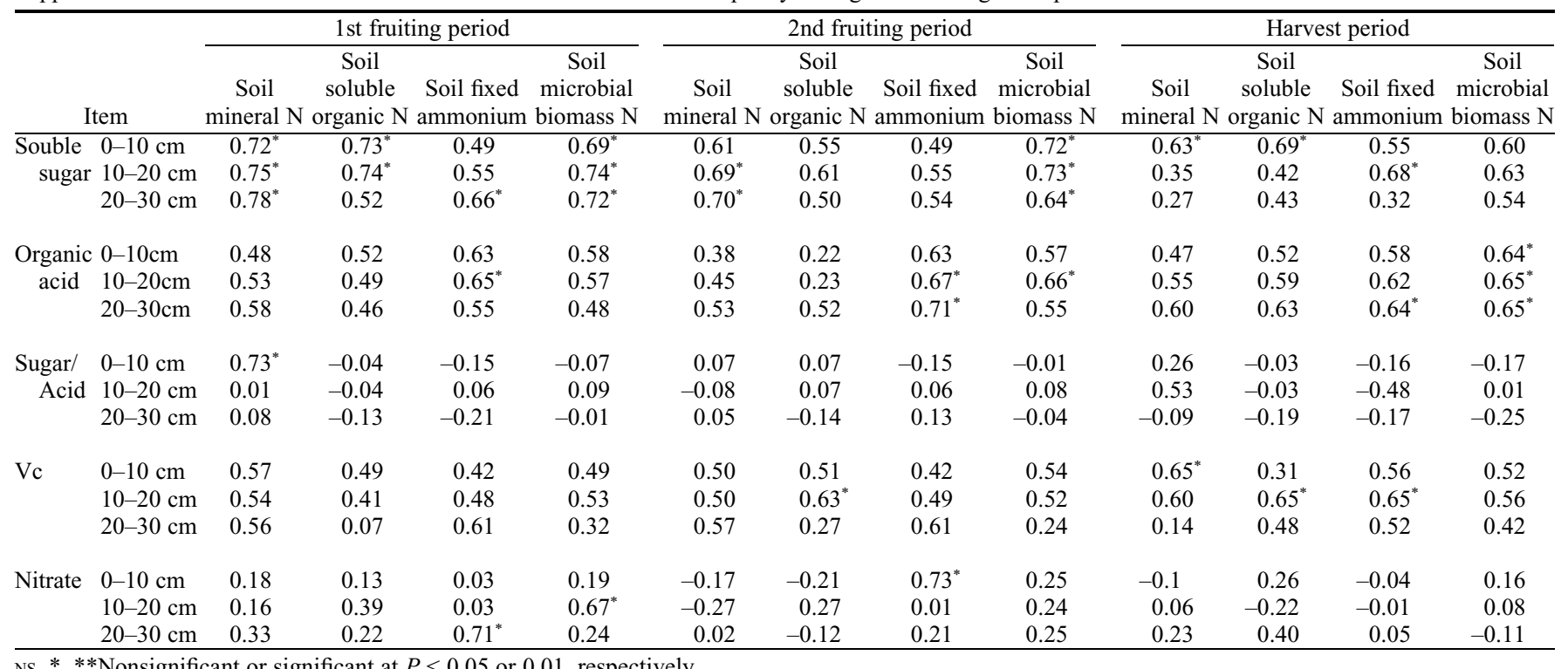

